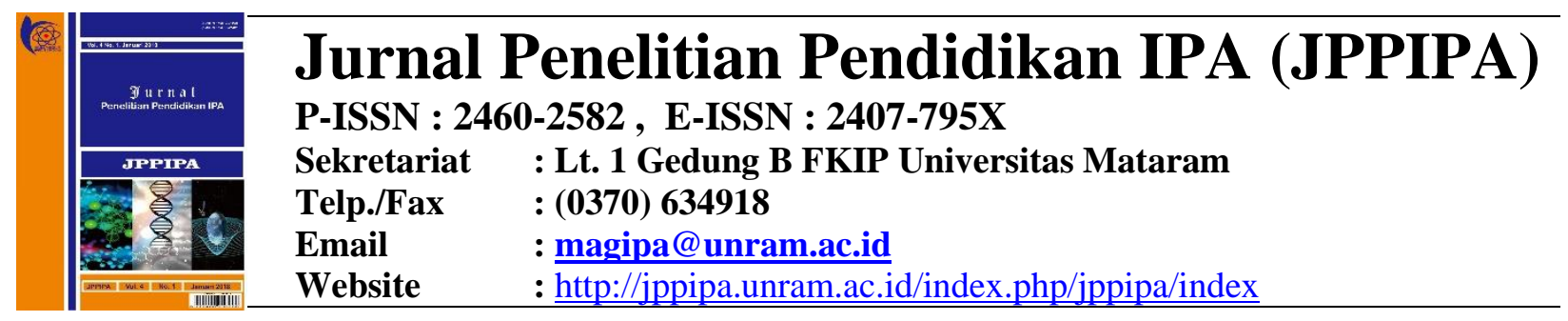

\title{
PENGEMBANGAN INSTRUMEN PENILAIAN SIKAP ILMIAH SAINS SISWA SEKOLAH DASAR (SD) BERBASIS PENDIDIKAN KARAKTER
}

\author{
Ferdinandus Bele Sole ${ }^{1}$, Desak Made Anggraeni ${ }^{2}$ \\ Program Studi PGSD Program Studi Pendidikan Fisika \\ STKIP Weetebula \\ Email: ferdibs@yahoo.com, desak.madeanggraeni@yahoo.com
}

\begin{tabular}{|c|c|}
\hline Key Words & Abstract \\
\hline $\begin{array}{l}\text { Development } \\
\text { of Scientific } \\
\text { Attitude } \\
\text { Instrument, } \\
\text { Character } \\
\text { Education }\end{array}$ & $\begin{array}{l}\text { This study aims to develop scientific science attitudes assessment } \\
\text { instruments that can be used in elementary school-based values of character } \\
\text { education. This research is a research development (R \& D) conducted for } \\
\text { one year with preliminary study stage, product development, product trial } \\
\text { and product dissemination developed. A preliminary study was conducted } \\
\text { by surveying the implementation of the science assessment in primary } \\
\text { school. The preliminary study results show that teachers in } 10 \text { surveyed } \\
\text { schools have never implemented a scientific attitude assessment in science } \\
\text { learning. At the stage of product development, has developed a scientific } \\
\text { attitude assessment instrument that has been validated by experts. The } \\
\text { product trials were conducted in three stages: initial field test, main field } \\
\text { test and field operational test. In the initial field test, it was conducted in two } \\
\text { schools with } 20 \text { respondents in each class. Initial field test results show that } \\
\text { the instrument reliability level is good, but there are still some invalid items } \\
\text { that are } 11 \text { items in class IV, } 8 \text { items in class V and } 7 \text { items in class VI. This } \\
\text { is because there are still some respondents who have not read smoothly so } \\
\text { that they have difficulty in answering questions. In the main field test, it was } \\
\text { conducted in } 8 \text { schools with } 91 \text { respondents. The main field test result is that } \\
\text { there are } 5 \text { invalid questions, both in class IV, V and VI. Operational field } \\
\text { tests were carried out with the number of respondents each } 13 \text { students from } \\
10 \text { schools. Field operational test results are all items declared valid and } \\
\text { reliable. The last stage is to disseminate products through scientific forums } \\
\text { such as seminars and socialization to schools. The scientific attitude } \\
\text { instruments developed in this study can be used by elementary teachers to } \\
\text { assess the scientific attitudes of elementary students. }\end{array}$ \\
\hline Kata & ostrak \\
\hline $\begin{array}{l}\text { Pengembangan } \\
\text {, Instrumen } \\
\text { Sikap Ilmiah } \\
\text { Sains, } \\
\text { Pendidikan } \\
\text { Karakter. }\end{array}$ & $\begin{array}{l}\text { Penelitian ini bertujuan untuk mengembangkan instrumen penilaian sikap } \\
\text { ilmiah sains yang dapat digunakan di SD berbasis nilai-nilai pendidikan } \\
\text { karakter. Penelitian ini merupakan penelitian pengembangan }(\mathrm{R} \& \mathrm{D}) \text { yang } \\
\text { dilakukan selama satu tahun dengan tahapan studi pendahuluan, } \\
\text { pengembangan produk, uji coba produk dan diseminasi produk yang } \\
\text { dikembangkan. Studi pendahuluan dilakukan dengan cara survei terhadap } \\
\text { implementasi penilaian IPA di SD. Hasil studi pendahuluan menunjukkan } \\
\text { bahwa guru-guru di } 10 \text { sekolah yang disurvey tidak pernah }\end{array}$ \\
\hline
\end{tabular}


mengimplementasikan penilaian sikap ilmiah dalam pembelajaran sains. Pada tahapan pengembangan produk, telah dikembangkan instrumen penilaian sikap ilmiah yang telah divalidasi oleh ahli. Uji coba produk dilaksanakan dalam tiga tahapan yakni uji lapangan awal, uji lapangan utama dan uji lapangan operasional. Pada uji lapangan awal, dilaksanakan di dua sekolah dengan jumlah responden 20 siswa pada masing-masing kelas. Hasil uji lapangan awal menunjukkan bahwa tingkat reliabilitas instrumen baik, namun masih terdapat beberapa item yang tidak valid yakni 11 item dikelas IV, 8 item di kelas V dan 7 item dikelas VI. Hal ini disebabkan masih terdapat beberapa responden yang belum lancar membaca sehingga mengalami kesulitan dalam menjawab pertanyaan. Pada uji lapangan utama, dilaksanakan di 8 sekolah dengan jumlah responden 91 siswa. Hasil uji lapangan utama adalah masih terdapat 5 soal yang tidak valid, baik dikelas IV, V dan VI. Uji lapangan operasional dilaksanakan dengan jumlah responden masing- masing 13 siswa dari 10 sekolah. Hasil uji lapangan operasional adalah semua butir soal dinyatakan valid dan reliabel. Tahapan terakhir adalah mendiseminasikan produk melalui forum ilmiah seperti seminar dan sosialisasi ke sekolah-sekolah. Instrumen sikap ilmiah yang dikembangkan dalam penelitian ini dapat digunakan oleh para guru SD untuk menilai sikap ilmiah siswa SD.

\section{PENDAHULUAN}

Kemajuan suatu bangsa ditentukan oleh kualitas sumber daya manusia sebagai penggerak tatanan kehidupan bangsa tersebut. Manusia yang berkualitas dapat dilihat dari nilai karakter yang dimilikinya. Menurut Asmani (2011: 19), karakter yang kuat akan membentuk mental yang kuat sehingga menumbuhkan spirit yang kuat pula. Karakter tersebut dapat ditunjukkan melalui pribadi yang pantang menyerah dan berani berproses. Karakter seperti ini sangat dibutuhkan dalam medan kompetisi di era global ini. Apabila setiap masyarakat Indonesia adalah manusia yang berkarakter kuat, terlebih dengan sumber daya alam yang melimpah, bukan mustahil bagi Indonesia untuk menjadi bangsa yang unggul.

Saat ini, upaya pemerintah untuk memaksimalkan pembentukan karakter individu melalui pendidikan karakter makin gencar dilaksanakan mulai dari jenjang pendidikan dasar hingga pendidikan tinggi. Beberapa upaya untuk mendorong keberhasilan dalam membangun karakter siswa yaitu: 1) Tersedianya kurikulum dan modul yang berbasis karakter. 2)
Lingkungan yang nyaman dan menyenangkan. 3) Guru yang kompeten dan berkarakter. 4) Mengimplementasikan pendidikan karakter dalam pembelajaran seperti pada aspek sikap ilmiah (scientific attitude) dalam pembelajaran sains SD.

Sulistyorini (2007: 9) yang mengemukakan bahwa pada hakikatnya sains dapat dipandang dari segi produk, proses dan segi pengembangan sikap. Artinya, belajar sains memiliki tujuan dari dimensi proses, dimensi hasil (produk), dan dimensi pengembangan sikap ilmiah. Ketiga dimensi tersebut bersifat saling terkait. Ini berarti bahwa proses belajar mengajar sains seharusnya mengandung ketiga dimensi tersebut. Tujuan pembelajaran di atas menyiratkan bahwa pembelajaran sains mencakup berbagai aspek dan tidak hanya berorientasi pada pencapaian hasil belajar aspek kognitif saja. Aspek lain yang juga penting untuk dipahami adalah aspek ketrampilan proses dan aspek sikap serta aplikasinya dalam bidang lain atau dalam kehidupan sehari-hari.

Pada implementasinya, pembelajaran sains SD masih terfokus pada aspek produk sains saja yaitu muatan pengetahuan yang 
harus dikuasai oleh siswa seperti sejumlah fakta dan konsep. Aspek proses, sikap dan aplikasi sains belum sepenuhnya dilaksanakan oleh guru. Hal ini dapat dilihat dari proses pembelajaran dimana guru hanya berfokus pada pencapaian target ketuntasan materi pada setiap semester guna memenuhi tuntutan kurikulum. Selain itu, penilaian yang dilakukan untuk mengukur pencapaian siswa masih terbatas pada aspek kognitif kognitif saja dan menjadi kriteria keberhasilan siswa dalam mempelajari sains. Hal ini tentu bertentangan dengan karakteristik sains dalam Kurikulum Tingkat Satuan Pendidikan yang berorientasi holistik, baik pada penguasaan konsep sains, proses penemuan konsep sains, dan juga sikap ilmiah.

Berdasarkan karakteristik sains tersebut maka model penilaian yang digunakan dalam pembelajaran sains seharusnya mencakup tiga dimensi tersebut. Menurut Patta Bundu (2006: 6), jika dicermati, hampir semua evaluasi hasil belajar formatif, sumatif bahkan evaluasi tahap akhir pun ditenggarai masih banyak mengevaluasi hasil belajar produk sains. Evaluasi biasanya lebih terfokus pada produk sains (materi) dan kurang memperhatikan bagaimana proses yang dilalui untuk menguasai produk tersebut. Memang diakui, baik hasil belajar produk maupun proses keduanya penting dalam menilai hasil belajar yang dicapai siswa, tetapi perhatian sangat kurang diberikan pada evaluasi proses. Apalagi penilaian dari segi sikap ilmiah hampir belum pernah tersentuh sama sekali. Akibatnya, metode apapun yang digunakan dalam pembelajaran sains tanpa diikuti dengan evaluasi yang sesuai dengan karakteristiknya maka hasil belajar sains yang sesungguhnya tidak akan nampak. Berdasarkan permasalahan tersebut, maka perlu dikembangkan suatu instrumen penilaian sikap ilmiah IPA siswa SD.

Dalam dunia sains, sikap ilmiah sebagai "science atitudes" senantiasa melekat pada setiap ilmuan sains. Sikap ilmiah adalah sikap tertentu yang diambil dan dikembangkan oleh ilmuwan untuk mencapai hasil yang diharapkan (Iskandar, 1996/1997: 11).

Attitudes are mental predipositions toward people, objects, sujects, events, and so on (Martin, 2005: 12). Sikap diartikan sebagai kecenderungan mental terhadap manusia, obyek, subyek, kejadian-kejadian dan lainnya.

Dalam pembelajaran sains, sikap ilmiah sangat penting karena tiga faktor yakni bahwa sikap mempengaruhi kesiapan mental pada anak, sikap bukanlah bawaan dari lahir serta sikap merupakan dampak yang dinamis dari pengalaman.

Pengelompokan sikap ilmiah oleh para ahli sangat bervariasi. Wynne Harlen dalam Bundu (1993: 7) menguraikan sembilan aspek sikap ilmiah yang dapat dikembangkan pada anak usia sekolah dasar yakni sikap ingin tahu, sikap ingin mendapatkan sesuatu yang baru, sikap kerja sama, sikap tidak putus asa, sikap tidak berprasangka, sikap mawas diri, sikap bertanggung jawab, sikap berpikir bebas dan sikap kedisiplinan.

Menurut Gega (1997: 77), empat sikap pokok yang harus dikembangkan dalam sains adalah curiosity (ingin tahu), inventiveness (penemuan), critical thinking (berpikir kritis), and persistence (ketekunan). Ke-empat sikap ini tidak dapat dipisahkan antara satu dengan lainnya karena saling melengkapi. Sikap ingin tahu mendorong akan suatu penemuan baru yang dengan berpikir kritis akan meneguhkan pendirian dan berani untuk berbeda pendapat.

Penilaian pada sikap ilmiah menggunakan bentuk penilaian non tes. Menurut Patta Bundu (2006: 142), teknik penilaian non tes yang sering digunakan adalah pengamatan (observasi), melakukan wawancara (interview), menyebarkan angket (kuesioner), dan dokumen (dokumentasi). Dalam penelitian ini, teknik penilaian yang dikembangkan adalah teknik angket dengan menggunakan angket yang berbentuk skala sikap Likert. 
Pengukuran sikap ilmiah siswa sekolah dasar dapat didasarkan pada pengelompokan sikap sebagai dimensi atau aspek sikap yang selanjutnya dikembangkan indikator-indikator sikap untuk setiap dimensi sehingga memudahkan menyusun butir instrumen sikap ilmiah.

Karakter secara etimologis berasal dari bahasa Yunani yaitu kasairo yang berarti cetak biru, format dasar, sidik. Mounier dalam Hanum melihat karakter sebagai dua hal, pertama sebagai sekumpuylan kondisi yang telah diberikan begitu saja atau telah ada begitu saja dalam diri kita, karakter yang demikian ini dianggap sebagai sesuatu yang telah ada atau kodrat (given). Kedua, karaketr juga bisa dipahami sebagai tingkat kekuatan melalui mana seorang individu mampu menguasai kondisi tersebut. Karakter yang demikian ini disebut sebagai sebuah proses yang dikehendaki (willed).

Nilai-nilai karakter yang identifikasi cukup banyak, namun Kementerian Pendidikan Nasional telah menyepakati nilai-nilai inti yang akan di kembangkan dalam implementasi pendidikan karakter di Indonesia yakni cerdas, jujur, tangguh dan peduli.

Nilai-nilai sembilan pilar karakter yang dikembangkan oleh Indonesia Haritage Foundation (IHF) yang dikutip oleh Ratna Megawangi (2010) terdiri dari:
a. Cinta Tuhan dan alam semesta beserta isinya
b. Tanggung jawab kedisiplinan dan kemandirian
c. Kejujuran
d. Hormat dan santun
e. Kasih sayang, kepedulian, dan kerjasama
f. Percaya diri, kreatif, kerja keras, dan pantang menyerah
g. Keadilan dan kepemimpinan
h. Baik dan rendah hati
i. Toleransi, cinta damai, dan kesatuan.

Beberapa upaya untuk mendorong keberhasilan dalam membangun karakter siswa yaitu:

a. Tersedianya kurikulum dan modul yang berbasis karakter. Kurikulum disusun berdasarkan prinsip keterkaitan antar materi pembelajaran, tidak terkotakkotan, dan dapat merefleksikan dimensi, keterampilan, dengan menampilkan tema-tema yang menarik dan kontekstual.

b. Lingkungan yang nyaman dan menyenangkan. Lingkungan yang nyaman dan menyenangkan perlu diciptakan agar karakter siswa dapat dibentuk karena berkaitan dengan pembentukkan emosi positif siswa sehingga dapat mendukung proses pembentukkan empati, cinta, dan akhirnya nurani atau batin siswa.

c. Guru yang kompeten dan berkarakter. Dalam proses pembelajaran, sangat diperlukan kemampuan guru untuk membangun karakter siswa. Oleh karena itu salah satu faktor pendukung dalam membentuk siswa yang berkarakter, dibutuhkan guru yang berkarakter.

Penanaman nilai-nilai karakter ini dapat juga dilaksanakan melalui implementasi penilaian sikap ilmiah sains siswa SD karena nilai-nilai yang termuat dalam karakter relevan dengan nilai-nilai yang ingin ditanamkan dalam penilaian sikap ilmiah sains.

\section{METODE}

Penelitian ini merupakan jenis penelitian pengembangan $(R \& D)$ yang menggunakan model Borg \& Gall. Penelitian ini dilakukan dalam 4 tahapan, yaitu:

1. Studi pendahuluan

Studi pendahuluan dilakukan melalui kajian pustaka untuk mengkaji teoriteori yang berkaitan dengan sikap ilmiah IPA dan mengembangkan instrumen survei. Setelah itu, melakukan survei terhadap pelaksanaan penilaian IPA di SD. Melalui studi pendahuluan ini, diharapkan dapat mengetahui sejauh mana keterlaksanaan penilaian IPA di sekolah dasar di kabupaten Sumba Barat Daya, kendala-kendala yang dihadapi pihak sekolah dalam melaksanakan penilaian sikap ilmiah dan memperoleh masukan 
serta saran mengenai apa saja yang diharapkan dari pihak sekolah dalam rangka mendukung keberhasilan pelaksanaan penilaian IPA secara komprehensif.

2. Pengembangan produk

Pengembangan produk berupa instrumen penilaian sikap ilmiah IPA Siswa SD berdasarkan kajian hasil survei.

3. Uji lapangan

Uji lapangan yang akan dilakukan terdiri 3 bentuk yaitu uji lapangan awal (preliminary field), uji lapangan utama (operational field test) dan uji lapangan operasional (operational field test). Uji lapangan awal bertujuan untuk mengetahui kelayakan penggunaan instrumen penilaian sikap ilmiah IPA di sekolah dasar. Pada uji lapangan ini, produk yang telah dikembangkan digunakan beberapa responden yaitu siswa SD kelas IV-VI. Uji lapangan utama bertujuan untuk mengetahui tingkat kelayakan produk instrument penilaian sikap ilmiah. Uji lapangan operasional bertujuan untuk mengetahui tingkat efektivitas penggunaan instrument penilaian sikap ilmiah siswa SD.

4. Diseminasi produk hasil pengembangan Diseminasi produk hasil pengembangan dilakukan melalui sosialisasi pada forum ilmiah.

Teknik pengumpulan data yang digunakan dalam penelitian ini adalah teknik survey, angket dan tes. Teknik survey digunakan untuk mendapatkan data awal tentang implementasi penilaian IPA di SD. Teknik tes dimaksudkan untuk mendapatkan data tentang validitas dan reliabilitasnya. Data angket yang telah terkumpul kemudian dianalisis menggunakan teknik deskriptif kuantitatif untuk mendeskripsikan kualitas instrument. Untuk hasil uji coba soal tes dianalisis dengan menggunakan SPSS 20.

\section{HASIL DAN PEMBAHASAN}

Studi pendahuluan yang dilakukan dalam penelitian ini berupa kajian tentang berbagai pustaka sikap ilmiah sains dan melakukan survey terhadap implementasi pelaksanaan penilaian IPA di sekolah dasar. Untuk mendapatkan data tentang implementasi penilaian IPA di SD, maka dilakukan survey ke 10 sekolah dasar yang tersebar di beberapa kecamatan di kabupaten Sumba Barat Daya, baik sekolah negeri maupun sekolah swasta. Instrumen yang digunakan untuk melakukan survey ini berupa pertanyaan-pertanyaan terkait jenisjenis penilaian dalam pembelajaran IPA SD yang sering, jarang dan tidak pernah dilakukan oleh guru serta alasannya dan juga hambatan-hambatan dalam melaksanakan penilaian serta saran/masukkan.

Hasil survey awal ini menunjukkan data bahwa 10 sekolah yang di survey tidak pernah mengimplementasikan penilaian sikap ilmiah dalam pembelajaran sains. Alasan yang paling banyak dikemukakan yang juga merupakan hambatan bagi para guru adalah adalah bahwa mereka belum memahami tentang penilaian sikap ilmiah dan hanya menggunakan penilaian untuk aspek kognitif saja. Selain itu dikemukakan juga bahwa belum tersedianya instrumen penilaian sikap ilmiah yang dapat langsung digunakan oleh para guru. Melalui kolom saran, para guru menyarankan agar dapat dikembangan instrumen penilaian sikap ilmiah yang dapat langsung digunakan oleh para guru untuk menilai sikap ilmiah siswa.

Sesuai dengan hasil survey awal yang telah dilakukan, maka produk yang dikembangkan dalam penelitian ini berupa instrumen penilaian sikap ilmiah siswa sekolah dasar. Instrumen ini dikembangkan dengan mengadopsi indikator yang dikembangkan oleh Harlen (dalam Bundu, 2006). Berdasarkan indikator tersebut, dikembangkan instrumen penilaian sikap ilmiah.

Sesuai dengan hasil survey awal yang telah dilakukan, maka produk yang dikembangkan dalam penelitian ini berupa instrumen penilaian sikap ilmiah siswa sekolah dasar. Instrumen ini dikembangkan dengan mengadopsi indikator yang dikembangkan oleh Harlen (dalam Bundu, 
2006). Berdasarkan indikator tersebut, dikembangkan instrumen penilaian sikap ilmiah untuk setiap materi.

Instrumen sikap ilmiah yang telah dikembangkan kemudian divalidasi oleh ahli yaitu Dr. Harry Soeprianto dari Universitas Mataram. Setelah divalidasi, langkah selanjutnya adalah melakukan uji lapangan.

Kegiatan uji lapangan dilaksanakan dalam tiga tahapan yakni uji lapangan awal, uji lapangan utama, dan uji lapangan operasional.

Kegiatan uji lapangan awal dilaksanakan di dua sekolah dengan jumlah responden masing- masing sekolah adalah 10 siswa baik kelas IV, V dan VI. Data hasil uji lapangan awal dianalisis menggunakan bantuan SPSS 19. Setelah dianalisis, diperoleh data validitas dan reliabilitas instrumen.

Di kelas IV, jumlah instrumen sikap ilmiah yang dikembangkan adalah 33 butir soal. Setelah dilakukan uji lapangan, diperoleh data bahwa 33 butir soal tersebut reliabel dengan hasil uji reliabilitasnya sebesar 0,909. Sedangkan ditinjau dari validitasnya, terdapat 20 butir soal yang dinyatakan valid dan 13 butir soal yang tidak valid.

Di kelas $\mathrm{V}$, jumlah instrumen yang dikembangkan adalah 32 butir soal. Hasil analisis untuk reliabilitasnya adalah 0,916 dan dinyatakan reliabel. Sedangkan hasil analisis untuk validitas butirnya adalah terdapat 24 yang dinyatakan valid, 8 butir soal yang tidak valid.

Jumlah instrumen sikap ilmiah yang dikembangkan di kelas VI adalah 32 butir. Setelah dianalisis, tingkat reliabilitasnya adalah 0,904 sedangkan validitas butirnya adalah 23 butir yang dinyatakan valid dan 9 butir soal yang tidak valid. Pada uji lapangan awal, terdapat beberapa butir soal yang dinyatakan tidak valid. Hal ini disebabkan karena pengisian angket seperti ini baru pertama kali dilakukan, sehingga masih banyak siswa yang bingung cara mengerjakan. Selain itu, siswa masih kesulitan dalam memahami beberapa istilah yang digunakan dalam instrumen. Hal lain yang menyebabkan banyaknya butir soal yang tidak valid adalah masih terdapat beberapa siswa yang belum mampu membaca dengan baik sehingga menyulitkan dalam mengisi angket sikap ilmiah. Rincian hasil analisis validitas butir dan reliabilitas untuk uji lapangan awal dapat dilihat pada lampiran 4a.

Langkah selanjutnya adalah melakukan revisi instrumen berdasarkan hasil uji coba lapangan awal. Beberapa istilah yang tidak dipahami siswa diganti dengan istilah lain yang lebih mudah dipahami siswa. Setelah direvisi, kemudian dilanjutkan dengan melakukan uji lapangan utama.

Uji lapangan utama dilaksanakan di 7 sekolah dengan jumlah responden masingmasing sekolah adalah 13 siswa. Jumlah total seluruh responden adalah 91 siswa. Data uji lapangan utama dianalisis menggunakan bantuan SPSS 19. Pada tahap ini, untuk uji reliabilitas instrumen, semua instrumen dinyatakan reliabel dengan tingkat reliabilitas untuk kelas IV, V dan VI adalah 0,$911 ; 0,915$ dan 0,921 . Sedangkan validitas butirnya, masing-masing kelas terdapat 5 instrumen yang tidak valid. Rincian hasil analisis validitas butir dan reliabilitas untuk uji lapangan utama dapat dilihat pada lampiran 4b. Berdasarkan hasil uji lapangan ini, kemudian dilakukan revisi instrumen dan dilanjutkan dengan uji lapangan operasional.

Pada tahapan ini, uji coba instrumen dilakukan pada 10 sekolah dengan jumlah responden pada masing-masing sekolah adalah 13 siswa. Jumlah total seluruh responden pada uji lapangan operasional adalah 130 siswa baik pada kelas IV, V dan VI. Hasil uji coba instrumen dianalisis menggunakan SPSS 19. Ditinjau dari aspek reliabilitas, semua instrumen dinyatakan reliabel, baik pada kelas IV, V dan VI dengan nilai reliabilitas masing-masingmasing adalah 0,$950 ; 0,953$ dan 0,926 . Hasil analisis validitas butir menyatakan bahwa semua butir dinyatakan valid baik pada kelas IV, V dan VI. Langkah terakhir adalah melakukan diseminasi produk yang sudah 
dikembangkan. Kegiatan diseminasi dilakukan di sekolah-sekolah yang menjadi mitra peneliti yakni 10 sekolah dasar di kabupaten Sumba Barat Daya dan disekolah-sekolah yang berada di sekitar STKIP Weetebula. Selanjutnya, dilakukan diseminasi produk melalui program pengalaman lapangan (PPL) di sekolahsekolah mitra PPL STKIP Weetebula. Diseminasi juga dilakukan melalui kegiatan forum ilmiah seperti seminar.

\section{KESIMPULAN}

Berdasarkan analisis data penelitian, dapat disimpulkan bahwa hasil pra survey menunjukkan bahwa penilaian sikap ilmiah tidak pernah digunakan oleh guru sekolah dasar. Hal ini disebabkan karena kurangnya pemahaman guru tentang sikap ilmiah dalam pembelajaran sains serta tidak tersedianya instrumen sikap ilmiah yang dapat langsung digunakan oleh para guru SD. Oleh karena itu disarankan untuk dikembangkan instrumen penilaian sikap ilmiah bagi siswa sekolah dasar. Dalam penelitian ini telah menghasilkan instrumen penilaian sikap ilmiah sains siswa SD yang valid dan reliable yang dapat digunakan oleh para guru SD untuk menilai sikap ilmiah siswa SD.

\section{DAFTAR PUSTAKA}

Afandi, R. (2011). Integrasi Pendidikan Karakter dalam Pembelajaran IPS di Sekolah Dasar. Jurnal Pedagogia, Volume I , Nomor(1), Universitas Muhammadiyah Sidoharjo.

Asmani, J.M. (2011). Buku Panduan Internalisasi Pendidikan Karakter di Sekolah. Yogyakarta: Diva Press.

Borg, W., R \& Gall, D. (1983). Educational Research: An Introduction. New York. Longman Inc.

Dharma, K. C., T. Johar, P. (2011). Pendidikan Karakter: Kajian Teori dan Praktik di Sekolah. Bandung. PT Remaja Rosda Karya.

Gega, P.C. (1997). Science Teaching in Elementary Education. New York. John Wiley \& Son.
Gufron, A. (2005). Model Pengembangan

Sistem Pembelajaran Bagi

Penyiapan Sumber Daya Manusia Era Reformasi. Makalah Penyerta dalam Seminar Nasional Teknologi Pembelajaran "Teknologi Pembelajaran Menuju Masyarakat Belajar" pada tanggal 5-6 Desember 2005.

Hidayati, S.P.(2012). Pengaruh Metode Kerja Laboratorium dan Demonstrasi Terhadap Keterampilan Proses Dasar IPA dan Sikap Ilmiah Peserta Didik Kelas VII SMP Darul Hikmah Kutoarjo. Tesis tidak diterbitkan. Yogyakarta: Universitas Negeri Yogyakarta.

Iskandar, S.M. (1997). Pendidikan Ilmu Pengetahuan Alam. Jakarta: BP3GSD Dirjen Dikti

Kartono. (2012). Pengembangan Model Penilaian Sikap Ilmiah IPA bagi Mahasiswa PGSD. Diambil pada tanggal 2 April 2016, dari eprints.uns.ac.id/15202/1/Publikasi_ Jurnal_(37).pdf.

Martin, R. et al.. (2005). Teaching Science For All Children : Inquiry Method For Contructing Understanding-3 $E d$. New York: Pearson Education.

Mudilanto. (2013). Membangun Karakter Anak Pendidikan Sains. Jurnal Pendidikan Karakter, Tahun III, Nomor 1, Universitas Negeri Yogyakarta.

Bundu, P. (2006). Penilaian Ketrampilan Proses dan Sikap Ilmiah dalam Pembelajaran Sains SD. Jakarta: Depdiknas.

Sulistyorini, S. (2007). Model Pembelajaran SAINS Sekolah Dasar dan Penerapannya dalam KTSP. Semarang: Tiara Wacana.

Zulnuraini. 2012. Pendidikan Karakter Konsep, Implementasi dan Pengembangannya di Sekolah Dasar di Kota Palu. Jurnal Dikdas, I (1), UNTAD. 